\title{
Prevalence of traumatic brain injury and mental health problems among individuals within the criminal justice system
}

Traumatic brain injury (TBI) is associated with increased aggression and antisocial behavior. This review examined existing literature regarding TBI prevalence and associated adverse mental health among individuals within the criminal justice system. TBI prevalence varied between 12 and $82 \%$ for youths, and 23 and $87 \%$ for adults. TBI was associated with a range of negative outcomes, particularly substance abuse. However, confounding factors, including differing control groups, lack of information for timing and severity of TBI, and use of self-report measures for TBI history made it difficult to determine whether TBI was a risk factor. Future research should eliminate or counter for these confounds, to provide accurate prevalence rates of TBI and the direction of association between TBI and offending behaviors.

First draft submitted: 16 June 2016; Accepted for publication: 26 October 2016; Published online: 25 November 2016

Keywords: • brain injury • incarcerated $\bullet$ mental health

\section{Background}

A long history associating traumatic brain injury (TBI) with antisocial behavior exists. Therefore, it is not surprising that there is an increasing interest in defining the impact of TBI on the criminal justice system in terms of defining potential causal factors for the likelihood of initial offending, challenging behavior during incarceration and recidivism. Early reviews on the determinants of violence identified TBI as a predictor of delinquency [1]. Research regarding children and adults on death row reported a correlation between conviction and a history of TBI, finding that $100 \%$ of adults and $57 \%$ of children had evidence of TBI in their medical histories $[2,3]$.

\section{Birth cohort data}

Studies utilizing cohort data have found compelling evidence regarding an increase in offending behavior for those with a history of TBI that predates offending. For instance, a large population birth cohort $(n=12,058)$ recruited from northern Finland was prospectively followed up until the age of 31 years ( $\mathrm{n}=5589$ males and $\mathrm{n}=5345$ females) [4]. In exploring associated outcomes, it was found that after controlling for confounding factors, TBI during childhood or adolescence was significantly related to later mental health disorders, with co-existing criminal behaviors evident in male cohort members (odds ratio: 4.1; 95\% CI: 1.2-13.6) [4]. Likewise, data from the Christchurch Health and Development Study birth cohort $(n=1265)$ were used to examine outcomes of individuals between the age of 0 and 21 years with a medically verified occurrence of TBI, which required hospitalization [5]. Findings indicated that after adjusting for child and family factors, these individuals were significantly more likely to report being arrested, have drug dependence and a history of violent offences when evaluated at 25 years of age [5]. While useful in highlighting correlations between participation in criminal offending and TBI, birth cohort data do not provide
Audrey McKinlay*,1 \& Michelle Albicini ${ }^{2}$ 'Melbourne School of Psychological Science, The University of Melbourne, Melbourne, Australia

${ }^{2}$ School of Psychological Sciences, Monash University, Melbourne, Australia *Author for correspondence:

audrey.mckinlay@unimelb.edu.au

Future
Medicine $\mathrm{fS}$ 
rates of TBI among individuals within the criminal justice system.

\section{Neurobiology}

It would be expected that if TBI were causally linked to offending, then supporting evidence would be available which highlights an association between damage to certain areas of the brain and antisocial behavior. Research has shown that specific areas of the cortex serve to regulate emotions [6], including the prefrontal cortex, the anterior cingulate cortex, the posterior right hemisphere and the insular cortex, and also a number of subcortical structures including the amygdala, hippocampus and thalamus (see [6] for review). Imaging studies can, therefore, identify the potential neurobiology associated with TBI that increase the likelihood offending behavior [7]. Emotion regulation is known to involve a complex interaction between cortical and subcortical systems [8]; however, patients with early onset ventral medial lesions are consistently reported as having difficulty comprehending the future consequences of risky behaviors [9]. In addition, patients with orbital frontal lesions have been found to have poor impulse control, difficulty perceiving social signals and difficulties with decision making $[10,11]$. And finally, damage to the anterior cingulate cortex has been found to have a role in altering perception of pain [12].

\section{Support for neurobiology}

Given the above associations between TBI and deficits in specific brain regions, it is not surprising that people with TBI have been reported to have difficulties interpreting the facial cues of others [13], and are more likely to have diminished insight into their actions or the consequence of their actions [9]. Moreover, individuals with TBI have been reported to respond more aggressively in certain situations. Increases in aggression are particularly relevant given the link between aggression and offending behaviors [14]. Baguley et al. [14] examined the prevalence of aggression among a sample of individuals with TBI $(\mathrm{n}=228)$ at 6,24 and 60 months postdischarge, and reported that at any given followup period, $25 \%$ of participants were classified as aggressive. Moreover, aggression was associated with depression, concurrent traumatic complaints and lower life satisfaction [14]. Similarly, aggression rates were examined in 67 individuals with a history of TBI who were recruited from an acute trauma unit and seen 3 months postinjury [15]. In this group, the prevalence of aggression was found to be over $28 \%$, and was associated with new onset depression and poorer social functioning [15].

Despite the correlation between TBI and offending behavior, there is still considerable inconsistency regarding its prevalence among individuals within the criminal justice system. Further, where increased lifetime prevalence of TBI is identified within such populations, the direction of the association is still not clear, and may be linked to a number of pathways. For example, individuals within the criminal justice system are more likely to experience a TBI while they are incarcerated due to being involved in physical fights. In addition, children exposed to neglectful parents are more likely to be exposed to high-risk activities, thereby increasing the risk of both sustaining a TBI and also developing delinquent behavior later in life. Therefore, to more clearly elucidate these factors, this review will critically examine the current literature on lifetime prevalence of TBI in individuals presenting within the criminal justice system. Additionally, the mental health outcomes of such individuals with a history of TBI will be explored with a view to answering the following questions:

- What is the lifetime prevalence of TBI among individuals present within the criminal justice system?

- Is TBI more frequent among criminal justice populations than those within the general population?

- Is TBI among criminal justice populations associated with increased negative behavioral, psychological or social outcomes (mental health disorders, cognitive deficits among others)?

- Is there a link between TBI and criminal offending behaviors among criminal justice populations?

\section{Methods}

A systematic review of academic journal articles was undertaken. For inclusion, studies needed to be written in the English language, have results about individuals within the criminal justice system, report on adult or child prevalence rates and include a definition for TBI. A systematized literature search was conducted using the following search engines: Ovid MEDLINE (1946-September 2016), PsycINFO (1806-September 2016) and Google Scholar. A search was conducted in each database using the terms 'traumatic brain injury' or 'head injury' and 'criminal behaviors' or 'crime' or 'criminals' or 'offending behaviors' or 'antisocial behaviors'. Returned articles were screened by title, abstract or full-text accordingly. The search returned a total of 142 articles. Of these, 84 were screened by title, 20 screened by abstract and ten examined by fulltext. Articles were excluded if they were found to be unrelated to the review's scope and aims, not including individuals within the criminal justice system as a sample of interest, not original research papers and dupli- 
cates. Manuscripts related specifically to individuals on death row were excluded as they are not representative of the general prison population, and separate reviews have been conducted specifically for this group, for example [16]. Manual searching for additional manuscripts based on the reference lists of relevant papers was also conducted, and papers reviewed based on inclusion criteria. The final result included 29 studies fitting the above criteria to be analyzed in the review.

\section{Results \& discussion}

What is the lifetime prevalence of TBI among individuals present within the criminal justice system?

Determining the lifetime prevalence of TBI among individuals within the criminal justice system is important. As outlined earlier, TBI has been associated with increased aggression and behavioral dysfunction that will likely disrupt rehabilitation efforts and negatively impact upon the maintenance of social support networks [17]. Youth and adults within the criminal justice system need to be considered separately as biologically, youth are still in the process of developmental change $[18,19]$. Because of psychosocial immaturity, youth with TBI are likely to have increased difficulties compared with adults in the criminal justice system with the same history. Further, interventions designed to reduce recidivism will have a different focus for youths versus adults [20].

As is evident in Table 1 (literature search results regarding adults within the criminal justice system) and Table 2 (literature search results for adolescents and youths within the criminal justice system), prevalence rates of TBI vary widely, with estimates between 12 and $82 \%$ for the adolescent and youth populations, and 23 and $87 \%$ for adults. The variability in prevalence rates that is reported across studies is likely due to a number of factors, including large variation in the age of different samples, differences among sample inclusion criteria and diversity of countries from which the rates are extracted, which included the UK, the USA, Australia and New Zealand.

Arguably, the most confounding factor for the accurate identification of TBI prevalence rates among individuals within the criminal justice system is the different terminologies and definitions used for TBI. Inclusion criteria have varied greatly, with some studies requiring a self-report of concussive symptoms (headaches, dizziness, among others), while others include those with a period of loss of consciousness (LOC). For example, as shown in Table 2, one study required a self-reported LOC of $>20$ min to determine TBI [43], while another, as summarized in Table 1, required a self-report of head injury or concussive symptoms [26].
Further, while most studies carefully elicit information about the mode of injury which could have resulted in TBI (i.e., falls, vehicle collisions, fights), the terminology used to assess the prevalence of TBI varied, with researchers using terms 'head injury', 'concussion' and 'TBI' interchangeably. However, lay persons generally have very little knowledge about what constitutes a TBI and may or may not report an injury depending which term is used [50]. Researchers have previously pointed out the importance of careful questioning regarding the incidence of TBI to elicit recall [31]. For example, a single question may be misinterpreted by the informant (self or significant other), depending on whether there is sufficient cueing to enhance recall. It has previously been pointed out that one or two items on a self-report is likely to underestimate lifetime exposure of TBI events and that questioning by a trained interviewer is likely to increase recall [51]. Further, careful consideration should be given to females where mode has been intimate partner abuse and not recognized as TBI [52].

To accurately determine lifetime prevalence of TBI among populations of individuals within the criminal justice system, research requires consistency among samples and the measures utilized which serve to elicit information about a TBI event. Further, the measures must ensure that the respondents are aware of different terminology used to denote injury including slang (e.g., 'getting the bash'), as well as typical mode of injury that results in TBI, in order to cue and elicit accurate recall.

\section{Gender issues}

There is very little information regarding females in criminal justice populations from which the prevalence of TBI or outcomes associated with a history of a TBI event can be evaluated. To date, the vast majority of studies examining criminal justice populations have focused on males. Where prevalence of females with TBI is examined, the trend found in the general population is mirrored in criminal justice populations, with men outnumbering women. For example, Colantonio et al. [35] surveyed 235 males and females within the criminal justice system, and found a self-reported prevalence of $50.4 \%$ for males and $38 \%$ for females. Alternatively, in an evaluation of the lifetime prevalence of self-reported TBI for 991 males and 88 females within the criminal justice system, slightly lower rates were identified, with $32 \%$ for males and $22.7 \%$ for females [37]. Unfortunately, females were not included in analyses that examined timing of first injury for TBI compared with that of non-TBI. Again finding different results, one large study reported a reverse trend with slightly higher rates for females ( $72 \%$ compared with 
Table 1. Prevalence of traumatic brain injury, among adults within the criminal justice system.

\begin{tabular}{|c|c|c|c|c|c|c|}
\hline Study & Participants & TBI definition & $\begin{array}{l}\text { TBI } \\
\text { predating } \\
\text { offending }\end{array}$ & Control & Outcome & Ref. \\
\hline 1. & $\begin{array}{l}19-27 \text { years } \\
\mathrm{n}=129 \\
\text { Mean } 21 \text { years } \\
100 \% \text { males }\end{array}$ & $\mathrm{SR}-\mathrm{HI}$ & NR & $\begin{array}{l}\text { First } 41 \text { detainees } \\
\text { interviewed } \\
\text { without } T B I\end{array}$ & $\begin{array}{l}\text { Prevalence of } \mathrm{TBI}=31.7 \% \\
\uparrow \text { Rule violations for individuals } \\
\text { with } \mathrm{TBI}\end{array}$ & [21] \\
\hline 5. & $\begin{array}{l}n=49 \\
\text { Mean } 35 \text { years } \\
36 \text { charged with } \\
\text { violent offences } \\
100 \% \text { male }\end{array}$ & $\begin{array}{l}\text { SR - blow to head/ } \\
\text { head injury }\end{array}$ & NR & $\begin{array}{l}\text { Nonviolent } \\
\text { detainees }\end{array}$ & $\begin{array}{l}\text { Prevalence of TBI }=77.8 \% \text { (violent) } \\
\text { vs } 46.2 \% \text { (nonviolent) } \\
\text { Severity of TBI linked to violent } \\
\text { offending } \\
\text { TBI plus learning disability/school } \\
\text { behavioral problems increases risk } \\
\text { of delinquent behavior }\end{array}$ & [25] \\
\hline 7. & $\begin{array}{l}\mathrm{n}=113 \\
18-52 \text { years } \\
\text { Mean } 33.2 \text { years } \\
100 \% \text { females ( } 27 \\
\text { with violent offences) }\end{array}$ & $\begin{array}{l}\text { SR supported by } \\
\text { visible damage } \\
\text { to skull or face }+ \\
\text { medical records }\end{array}$ & $\begin{array}{l}\text { Age at first } \\
\text { conviction }\end{array}$ & $\begin{array}{l}86 \text { nonviolent } \\
\text { detainees }\end{array}$ & $\begin{array}{l}\text { Prevalence }=42 \% \text { with } \geq 1 \text { TBI } \\
\text { events with LOC } \\
95 \% \text { of entire sample }= \\
\text { neurological abnormalities } \\
\text { predating current crime } \\
\text { Cortisol correlated with higher } \\
\text { number of TBI with LOC } \\
\text { Hx of TBI significantly higher in } \\
\text { those with violent offences }\end{array}$ & {$[27]$} \\
\hline 8. & $\begin{array}{l}\mathrm{n}=200 \\
18-40+\text { years } \\
\text { Mean } 30.6 \text { years } \\
100 \% \text { males }\end{array}$ & $\begin{array}{l}\text { SR }-\mathrm{HI} \text { with/ } \\
\text { without LOC, } \\
\text { medical validated } \\
(70 \%)\end{array}$ & NR & $\begin{array}{l}\text { Detainees } \\
\text { without TBI }\end{array}$ & $\begin{array}{l}\text { Prevalence of } \mathrm{TBI}=82 \% \\
\mathrm{Hx} \mathrm{TBI}=2.5 \times \text { more likely to have } \\
\text { drug abuse problem } \\
\mathrm{Hx} \text { TBI with } \mathrm{LOC}=\uparrow \text { depression }\end{array}$ & {$[28]$} \\
\hline
\end{tabular}


Table 1. Prevalence of traumatic brain injury, among adults within the criminal justice system (cont.).

\begin{tabular}{|c|c|c|c|c|c|c|}
\hline Study & Participants & TBI definition & $\begin{array}{l}\text { TBI } \\
\text { predating } \\
\text { offending }\end{array}$ & Control & Outcome & Ref. \\
\hline 9. & $\begin{array}{l}\mathrm{n}=100 \\
18-40+\text { years } \\
\text { Mean } 30.6 \text { years } \\
100 \% \text { males }\end{array}$ & $\begin{array}{l}\text { SR }-\mathrm{HI} \text { with/ } \\
\text { without LOC, } \\
\text { medical validated } \\
(70 \%)\end{array}$ & NR & $\begin{array}{l}\text { Not relevant } \\
\text { characteristics of } \\
\text { TBI reported }\end{array}$ & $\begin{array}{l}\text { Prevalence of } \mathrm{TBI}=82 \% \\
\mathrm{LOC} \text { for } 79 \% \text { of } \mathrm{TBI} \text { cases } \\
43 \%=\geq 4 \mathrm{TBIs} \\
\text { Two-thirds of } \mathrm{TBI} \text { with } \mathrm{LOC}= \\
\text { reported requiring medical care } \\
52 \% \text { of } \mathrm{TBI}=\text { reported ongoing } \\
\text { problems mean of } 7 \text { years } \\
\text { postinjury }\end{array}$ & [29] \\
\hline 10. & $\begin{array}{l}\mathrm{n}=394 \\
\text { Mean } 37.3 \text { years } \\
\mathrm{n}=248 \text { males }(63 \%)\end{array}$ & $\begin{array}{l}S R+\text { file review, } \\
\text { evidence of LOC }\end{array}$ & $\begin{array}{l}\text { Medical } \\
\text { evidence } \\
\text { for some }\end{array}$ & $\begin{array}{l}\text { Detainees } \\
\text { without } \mathrm{Hx} \text { of } \mathrm{TBI}\end{array}$ & $\begin{array}{l}\text { Prevalence of TBI }=22.6 \% \text { ( } 92 \% \\
\text { male) } \\
\text { SR ( } 73 \% \text { or documented in health } \\
\text { records) } \\
\text { LOC from } 1 \text { day to } 36 \text { weeks } \\
\text { TBI Hx associated with } \uparrow \text { alcohol/ } \\
\text { substance abuse }\end{array}$ & [30] \\
\hline 11. & $\begin{array}{l}n=256 \\
18+\text { years } \\
n=107 \text { males }(41 \%)\end{array}$ & $\begin{array}{l}\text { SR - } 15 \text { questions } \\
\text { related to lifetime } \\
\text { Hx of head injury }\end{array}$ & NR & Not applicable & $\begin{array}{l}\text { Prevalence of } \mathrm{TBI}=88 \% \\
\text { Mean number } \mathrm{TBI}=3 \text { per person } \\
50 \% \text { of } \mathrm{TBI} \text { resulted in } \mathrm{LOC}\end{array}$ & [31] \\
\hline 12. & $\begin{array}{l}\mathrm{n}=210 \\
18-55 \text { years } \\
\text { Mean } 32.7 \text { years } \\
\mathrm{n}=105 \text { males }(50 \%)\end{array}$ & $\begin{array}{l}\text { SR }-\mathrm{TBI} \\
\text { with altered } \\
\text { consciousness }\end{array}$ & NR & None & $\begin{array}{l}\text { Prevalence }=78 \% \text { with } \mathrm{TBI} \\
\text { Mean number } \mathrm{TBI}=2.5 \text { per person } \\
45 \% \text { with } \mathrm{TBI} \text { had no medical } \\
\text { attention }\end{array}$ & [32] \\
\hline 13. & $\begin{array}{l}\mathrm{n}=200 \\
18-56 \text { years } \\
\text { Mean } 30.6 \text { years } \\
100 \% \text { males }\end{array}$ & $\begin{array}{l}\text { SR - HI with / } \\
\text { without LOC }\end{array}$ & NR & $\begin{array}{l}\text { Community } \\
\text { sample } \mathrm{n}=200 \\
\text { men, no Hx of } \\
\text { arrest }\end{array}$ & $\begin{array}{l}\text { Prevalence of } \mathrm{TBI}=82 \% \text { in } \\
\text { criminal justice system vs } 72 \% \\
\text { community sample } \\
\text { LOC and multiple } \mathrm{TBI}=\text { more } \\
\text { common in criminal justice group } \\
\text { TBI associated with } \uparrow \text { impulsivity }\end{array}$ & [33] \\
\hline 15. & $\begin{array}{l}n=235 \\
18-45+\text { years } \\
\text { Mean } 34.4 \text { years } \\
n=131 \text { males }(56 \%) \\
104 \text { females }(44 \%)\end{array}$ & $\begin{array}{l}\text { SR - LOC or } \\
\text { concussion }\end{array}$ & NR & $\begin{array}{l}\text { Detainees } \\
\text { without TBI }\end{array}$ & $\begin{array}{l}\text { Prevalence of TBI = } 43.4-50.4 \% \\
\text { of all men, } 38 \% \text { of all women. } \\
\text { Females more likely to have TBI } \\
\text { prior to criminal activity than } \\
\text { males } \\
7 \% \text { of males and } 8 \% \text { of females } \\
\text { reported no substance abuse } \\
\text { Higher rates of abuse among } \\
\text { females with TBI } \\
\text { No difference between groups for } \\
\text { offences, majority nonviolent }\end{array}$ & [35] \\
\hline
\end{tabular}


Table 1. Prevalence of traumatic brain injury, among adults within the criminal justice system (cont.).

\begin{tabular}{|c|c|c|c|c|c|c|}
\hline Study & Participants & TBI definition & $\begin{array}{l}\text { TBI } \\
\text { predating } \\
\text { offending }\end{array}$ & Control & Outcome & Ref. \\
\hline 16. & $\begin{array}{l}n=831 \\
16-69 \text { years } \\
\text { Mean } 32.9 \text { years } \\
100 \% \text { males }\end{array}$ & $S R-T B I$ & $\begin{array}{l}\text { Examined } \\
\text { association } \\
\text { between } \\
\text { prior TBI } \\
\text { and current } \\
\text { offending }\end{array}$ & Not applicable & $\begin{array}{l}\text { Prevalence of } \mathrm{TBI}=35.7 \% \\
\text { Individuals with } \mathrm{Hx} \text { of } \mathrm{TBI} \text { and } \\
\text { incidence of incarceration } \\
\text { significant } \\
\uparrow \text { Psychiatric problems associated } \\
\text { with } \mathrm{Hx} \text { of } \mathrm{TBI}\end{array}$ & [36] \\
\hline 17. & $\begin{array}{l}n=1079 \\
18+\text { years } \\
\text { Mean } 30 \text { years } \\
n=991 \text { males }(92 \%), \\
88 \text { females }(8 \%)\end{array}$ & $\begin{array}{l}\mathrm{SR}-\mathrm{HI} \text { resulted in } \\
\text { LOC/or concussion }\end{array}$ & NR & $\begin{array}{l}\text { Detainees } \\
\text { without TBI }\end{array}$ & $\begin{array}{l}\text { Prevalence of } \mathrm{TBI}=32 \% \text { for males, } \\
22.7 \% \text { for females } \\
14 \% \text { of males sustained first TBI } \\
\text { in prison } \\
\text { Time in custody significantly } \\
\text { longer for those with TBI } \\
\text { Perceived health significantly } \\
\text { worse for TBI } \\
\text { TBI Hx } \uparrow \text { of psychiatric disorder } \\
\text { TBI group } \uparrow \text { regular cannabis use }\end{array}$ & [37] \\
\hline 18. & $\begin{array}{l}n=636 \\
\text { Mean } 35.5 \text { years } \\
18+\text { years } \\
n=316 \text { females } \\
(49 \%), 320 \text { males } \\
(51 \%)\end{array}$ & $S R-T B I$ & $\begin{array}{l}\text { Age of TBI } \\
\text { occurrence }\end{array}$ & $\begin{array}{l}\text { Detainees } \\
\text { without TBI }\end{array}$ & $\begin{array}{l}\text { Prevalence of } \mathrm{TBI}=68 \% \text { ( } 71.5 \% \\
\text { for females, } 64.1 \% \text { for males) } \\
51.1 \% \text { reported first drug use } \\
\text { prior to TBI } \\
\text { Hx TBI reported significantly } \\
\text { younger age of drug use initiation } \\
\text { TBI group } \uparrow \text { drug use severity }\end{array}$ & [38] \\
\hline 19. & $\begin{array}{l}n=38 \\
18+\text { years } \\
\text { Mean } 33 \text { years } \\
100 \% \text { females }\end{array}$ & $S R-T B I$ & $\begin{array}{l}\text { Age of TBI } \\
\text { occurrence }\end{array}$ & & $\begin{array}{l}\text { Prevalence of } \mathrm{TBI}=94.7 \% \\
\text { Younger age at injury associated } \\
\text { with } \uparrow \text { mental health problems }\end{array}$ & [39] \\
\hline
\end{tabular}

males 65\%) [34]. When exploring a female-only sample, consisting of 38 women within the criminal justice system, as many as $94 \%$ of participants self-reported a history of TBI [39].

Is TBI more frequent among criminal justice populations than those within the general population?

Determining whether prevalence of TBI is higher among individuals in the criminal justice system, when compared with individuals in the general population is difficult. TBI is very common within the general population, with prevalence rates varying depending on whether they are based on hospital discharge or population-based samples, general self-report or specific subsamples of nonincarcerated individuals [53,54]. Table 3 provides a sample of studies examining prevalence of TBI in the noncriminal justice system population. Prevalence rates differ depending on whether they are based on a medical diagnosis (5.7-31.0\%), self-report (31.0-44.0\%) or self-reported within specific vulnerable populations (29.5-80.0\%). Prevalence of verified TBI, using prospectively collected data from a birth cohort, has reported a lifetime prevalence of approximately $31 \%$ by the age of 25 years (38\% among males vs $24 \%$ for females) [55]. It has also been noted that children aged $0-5$ years, and males aged between 15 and 25 years, are at an increased risk for experiencing a TBI event [55,56]. Further predictors for individuals more at risk of having a TBI include male gender, high maternal punitiveness, and greater number of adverse life events [57], drug use, a history of mental illness and homelessness (see [58] for review).

Similar prevalence rates are evident for criminal justice versus noncriminal justice samples depending on the subpopulation from which they were drawn. Between 12 and $82 \%$ of youths within the criminal justice system self-reported TBI compared with between 31 and $50 \%$ of youth in the general population. In the nal justice system who also have high rates of drug use are similar.

The fact that research has found similar prevalence rates - depending on the subsample studied strongly suggests that rather than there being a direct 


\begin{tabular}{|c|c|c|c|c|c|c|c|c|}
\hline 1. & 316 & $\begin{array}{l}11-20 \text { years } \\
\text { Mean: } \\
15.4 \text { years }\end{array}$ & $67 \%$ males & $\begin{array}{l}\text { Parental } \\
\text { report } \\
\text { HI }\end{array}$ & NR & $\begin{array}{l}\text { School } \\
\text { youths } \\
n=437 \\
48 \% \text { males }\end{array}$ & $\begin{array}{l}\text { Prevalence of } \mathrm{TBI}=49.68 \% \\
\text { within criminal justice } \\
\text { system, } 42.1 \% \text { school youths }\end{array}$ & [40] \\
\hline 2. & 202 & $12-19$ years & $100 \%$ males & $\mathrm{SR}-\mathrm{HI}$ & NR & $\begin{array}{l}\text { School } \\
\text { youth } \\
\mathrm{n}=379 \\
100 \% \text { males }\end{array}$ & $\begin{array}{l}\text { Prevalence of } \mathrm{TBI}=\uparrow \text { among } \\
\text { youths in criminal justice } \\
\text { system ( } 12.5 \text { vs } 5.8 \%)\end{array}$ & {$[41]$} \\
\hline 3. & 242 & $\begin{array}{l}14-21 \text { years } \\
\text { Mean: } \\
17.2 \text { years }\end{array}$ & $\begin{array}{l}223 \text { males } \\
(92 \%), 19 \\
\text { females }(8 \%)\end{array}$ & $\begin{array}{l}\text { SR }- \text { TBI } \\
\text { blacked out } \\
\text { or LOC }\end{array}$ & NR & $\begin{array}{l}\text { Detainees } \\
\text { without TBI }\end{array}$ & $\begin{array}{l}\text { Prevalence of TBI = } 35.1 \% \\
\text { ( } n=1 \text { female with TBI) } \\
\text { TBI group = } 30.6 \% \text { reported } \\
\geq 1 \text { TBI } \\
\text { TBI group = } \uparrow \text { harmful } \\
\text { alcohol use } \\
50 \% \text { of those with TBI } \\
\text { reported cognitive or } \\
\text { behavioral problems } \\
\uparrow \text { severe violent offending } \\
\text { for those with } \mathrm{Hx} \text { TBI }\end{array}$ & {$[42]$} \\
\hline 4. & 723 & $\begin{array}{l}11-20 \text { years } \\
\text { Mean: } \\
15.5 \text { years }\end{array}$ & $87 \%$ males & $\begin{array}{l}\mathrm{SR}-\mathrm{HI} \\
\text { resulting in } \\
\mathrm{LOC}>20 \mathrm{~min}\end{array}$ & NR & $\begin{array}{l}\text { Detainees } \\
\text { without TBI }\end{array}$ & $\begin{array}{l}\text { Prevalence of } \mathrm{TBI}=18 \% \\
\mathrm{TBI} \text { group = more likely to } \\
\text { have } \mathrm{Hx} \text { of substance use } \\
\mathrm{TBI} \text { group = } \uparrow \text { mental illness } \\
\text { ( } 64 \text { vs } 49 \% \text { controls) } \\
\mathrm{TBI} \text { group = younger mean } \\
\text { age when first convicted } \\
\mathrm{Hx} \text { TBI = increase risk of } \\
\text { victimization ( } 89 \text { vs } 74 \% \\
\text { controls) }\end{array}$ & {$[43]$} \\
\hline 6. & 186 & $\begin{array}{l}11-19 \text { years } \\
\text { Mean: } \\
16.67 \text { years }\end{array}$ & $100 \%$ males & SR & NR & $\begin{array}{l}\text { Detainees } \\
\text { without TBI }\end{array}$ & $\begin{array}{l}\text { Prevalence of } \mathrm{TBI}=46 \% \text { with } \\
\mathrm{LOC} \text {, repeat } \mathrm{TBI}=32 \% \\
\mathrm{TBI} \mathrm{Hx}=\uparrow \text { rate of violence in } \\
\text { offences } \\
\mathrm{TBI} \text { group }=\uparrow \text { mental health } \\
\text { problems and cannabis use }\end{array}$ & {$[45]$} \\
\hline 7. & 61 & $\begin{array}{l}16-18 \text { years } \\
\text { Mean: } \\
16.87 \text { years }\end{array}$ & $100 \%$ males & $\begin{array}{l}\text { SR - HI with } \\
\text { LOC/or } \\
\text { concussion }\end{array}$ & NR & $\begin{array}{l}\text { Detainees } \\
\text { without TBI }\end{array}$ & $\begin{array}{l}\text { Prevalence of } \mathrm{TBI}=71 \% \\
\text { Increase in PCS with increase } \\
\text { in TBI severity } \\
\text { Severity of TBI related to } \\
\text { alcohol use }\end{array}$ & [46] \\
\hline
\end{tabular}


Table 2. Prevalence for traumatic brain injury, among adolescent and youth within the criminal justice system (cont.).

\begin{tabular}{|c|c|c|c|c|c|c|c|c|}
\hline Study & $\mathrm{n}$ & Age & Gender & $\begin{array}{l}\text { TBI } \\
\text { definition }\end{array}$ & $\begin{array}{l}\text { TBI } \\
\text { prior to } \\
\text { offending }\end{array}$ & Control & Outcome & Ref. \\
\hline 8. & 316 & $13-21$ years & $\begin{array}{l}277 \text { males } \\
(88 \%), 39 \\
\text { females } \\
(12 \%)\end{array}$ & $\begin{array}{l}\text { SR - HI with } \\
\text { LOC }\end{array}$ & NR & $\begin{array}{l}\text { Not } \\
\text { applicable }\end{array}$ & $\begin{array}{l}\text { Prevalence of } \geq 1 \mathrm{TBI}=32 \% \\
\text { Majority of TBI result of } \\
\text { assault } \\
31 \% \text { reported ongoing } \\
\text { neurological effects of TBI } \\
\text { TBI associated with } \\
\uparrow \text { psychological distress, Hx } \\
\text { of being bullied, alcohol, } \\
\text { drug use } \\
\text { TBI group = significantly } \\
\text { more likely to be } \\
\text { reincarcerated during } 18 \\
\text { months follow-up }\end{array}$ & {$[47]$} \\
\hline 10. & 93 & $\begin{array}{l}15-18 \text { years } \\
\text { Mean: } \\
16.5 \text { years }\end{array}$ & $100 \%$ males & $\begin{array}{l}\text { SR - BI with } \\
\text { LOC/or } \\
\text { concussion }\end{array}$ & NR & $\begin{array}{l}\text { Detainees } \\
\text { without TBI }\end{array}$ & $\begin{array}{l}\text { Prevalence of } \mathrm{TBI}=82 \% \\
55 \% \text { reported multiple } \mathrm{TBI} \\
44 \% \mathrm{TBI} \text { reported ongoing } \\
\text { concussive symptoms }\end{array}$ & [49] \\
\hline
\end{tabular}

个: Increased rate; HI: Head injury; BI: Brain injury; Hx: History; LOC: Loss of consciousness; PCS: Post-concussive symptom; SR: Self-report; TBI: Traumatic brain injury.

link between TBI and increased risk of involvement in criminal justice system, other social and economic factors may play a role in the association.

The almost exclusive reliance on self-report measures for identifying history of TBI within the criminal justice system populations, compared with that of general population estimates (which are usually derived from medically verified reports of TBI) is likely to lead to misleading results. The prevalence of TBI varies depending on the sample and method used to collect information. More specifically, the question of whether self-report is an accurate method of ascertaining lifetime prevalence among any population has not been well researched. As such, the nature of self-report measures in identifying TBI history will be considered here.

\section{Accuracy of self-report}

Accuracy of self-report for history of TBI has been examined for 112 individuals who provided access to medical records to confirm or deny a TBI diagnosis [67]. In cross-checking self-reported TBI events with medical records, moderate to strong evidence (true positives) was found for $66 \%$ of cases, and weak or no evidence (false positives) was found for $44 \%$ of cases. No information was available for TBI events that were not recalled (false negatives), or where no TBI event took place (true negatives) [67]. In a recent study using birth cohort data, individuals aged 25 years were asked to recall verified TBI events that occurred between the ages 0 and 10 years [68]. Researchers identified that those with a TBI that occurred between the ages of 0 and 5 years recalled $<10 \%$ of injuries accurately, and for individuals with a TBI event during the ages 6-10 years, 31\% were correctly recalled [68]. These results suggest that memory for TBI tends to improve with age and with severity of injury. However, in this study only $50 \%$ of injuries that involved a LOC were recalled. In a further study utilizing the same sample 
group, but restricting recall to $\mathrm{TBI}$ events that required hospitalization, self-report remained inaccurate; that is, just over $50 \%$ of the verified hospitalized TBI events were correctly recalled in the cohort [69]. Injury events involving LOC were associated with a higher level of recall accuracy, with $68 \%$ of hospitalized TBI events that resulted in LOC being recalled. However, a remaining $32 \%$ of hospitalized events with LOC were not recalled, and a large number of TBI events were incorrectly recalled (i.e., there was no evidence that the injuries had occurred) [69]. Further, individuals with multiple injuries often did not recall all of the injury events [69]. Even when considering more severe TBI events that occurred within 5 years prior to the assessment, not all occurrences were always reported, potentially due to being overshadowed by other accompanying injuries such as fractures or internal injuries to other organs. Of particular concern was the inaccuracy for early TBI, which was significantly less likely to be elicited via self-report in adulthood [69].

These studies demonstrate the inaccuracy of selfreport which is likely a result of a number of issues including being too young at the time of injury to have a memory for the event, forgetting due to time

\section{Table 3. Prevalence for traumatic brain injury in noncriminal justice populations for medically confirmed and} self-report in general and subpopulations.

\begin{tabular}{|c|c|c|c|}
\hline Participants & TBI definition & Prevalence of TBI & Ref. \\
\hline \multicolumn{4}{|l|}{ Medically identified TBI } \\
\hline $\begin{array}{l}n=7485 \\
\text { Males and females } \\
\text { Age }=20-64 \text { years }\end{array}$ & Self-report of serious head injury with LoC & $\begin{array}{l}\text { Prevalence }=5.7 \% \\
\text { involving } L O C \geq 15 \mathrm{~min}\end{array}$ & [52] \\
\hline $\begin{array}{l}n=1265 \\
\text { Males and females } \\
\text { Age }=0-25 \text { years }\end{array}$ & Medical diagnosis of TBI & Prevalence $=32 \%$ & [55] \\
\hline $\begin{array}{l}n=7170 \\
\text { Males and females } \\
\text { Age }=18-50+\text { years }\end{array}$ & Audit of medical records & $\begin{array}{l}\text { Prevalence }=23.9 \% \\
\text { mTBI }\end{array}$ & [59] \\
\hline \multicolumn{4}{|l|}{ Self-reported TBI } \\
\hline $\begin{array}{l}\mathrm{n}=616 \\
\text { Males and females } \\
\text { Age: } 18 \text { years }\end{array}$ & Self-report lifetime history of TBI & Prevalence $=31 \%$ & [60] \\
\hline $\begin{array}{l}n=135 \\
\text { Males and females } \\
\text { Age }=14-15 \text { years }\end{array}$ & Self-report history of TBI over last 3 years & 3 years prevalence $=44 \%$ & [62] \\
\hline $\begin{array}{l}n=2701 \\
\text { Males and females } \\
\text { Age: }>18 \text { years }\end{array}$ & Self-report lifetime history of TBI & Prevalence $=42.4 \%$ & [63] \\
\hline \multicolumn{4}{|l|}{ Self-report TBI for specific nonincarcerated sample } \\
\hline $\begin{array}{l}\mathrm{n}=173 \\
\text { Males and females } \\
\text { Individuals with HIV }\end{array}$ & Self-report lifetime history of TBI & Prevalence $=74 \%$ & [64] \\
\hline $\begin{array}{l}\mathrm{n}=295 \\
\text { Co-occurring mental illness and substance use }\end{array}$ & Self-report lifetime history of TBI & Prevalence $=80 \%$ & [66] \\
\hline
\end{tabular}


lapse since TBI, or other medical issues being more overt at the time of the injury and taking precedence (i.e., broken bones or internal injuries). As pointed out by Merbitz et al. [21], an additional problem associated with self-report for populations based within the criminal justice system is the possibility that the self-report of TBI may be given in order to receive a certain advantage (e.g., differential cell assignments or therapy opportunities), thereby increasing the rates of false positives.

Given the difficulties with self-report, other methods need to be considered to ensure accuracy in obtaining incidence and prevalence rates. These could include confirming self-report accident data with that of medical information or seeking collateral information from parents, or significant others.

\section{Criteria used to define TBI}

As outlined earlier, comparisons between self-reported TBI among individuals within the criminal justice system and the general population, are further complicated by the varying inclusion criteria used to determine whether a TBI has taken place. Within the general population, standard criteria are used to define mild/moderate and severe TBI. The presence of an LOC is not generally used as a lower inclusion criterion for mild TBI (see [70] for review of generally accepted criteria). However, five of the studies reviewed here used LOC as an inclusion criterion (see Tables 1 \& 2). The use of self-report and inclusion criteria that are different from those employed within the general population severely limit any attempt to compare prevalence rates between community and criminal justice system samples. Therefore, it is nearly impossible to determine whether individuals with TBI are more likely than the general population to engage in offending behavior unless the reports are compared with similar subsamples in the general population who have not been involved with the criminal justice system (as shown on Table 3).

Is TBI among criminal justice populations associated with increased behavioral, psychological or social negative outcomes (mental health disorders, cognitive deficits, among others)?

In many of the studies reviewed (Tables 1 \& 2), a selfreported history of TBI was found to be associated with a variety of negative outcomes, including deficits in cognition [23,43], higher rates of mental health problems [28,43], and increased rates of aggression [26,42]. Increases in violent offending were also linked to a history of TBI $[21,27]$. The most commonly reported negative outcome, however, was rates of drug abuse, which were recorded to be higher for those with TBI at any age compared with the control group [28,30,35,42-44,46]. The literature reviewed in Tables $1 \& 2$ suggests that individuals in the criminal justice system with a selfreported history of TBI do have a number of deficits and negative outcomes. However, some consideration needs to be given to the control groups used to quantify this increased risk.

\section{Control groups}

Most studies examining outcomes reviewed an association between TBI versus a control group (either a community group or individuals in the criminal justice system without TBI), without consideration about the appropriateness of the comparison/control group being utilized. For example, a number of the studies reviewed here (see Tables 1 \& 2) directly examined the association between a self-reported history of TBI among individuals who have committed violent versus nonviolent crimes $[25,27]$. However, violent offending is more often associated with physical altercation, which in itself increases the risk of a TBI event. This being the case, dividing groups into those who have committed a violent crime as compared with those who have not, and then eliciting information about a TBI history, will distort the outcome. This is particularly true considering that most of the research to date does not consider the timing of the TBI event (i.e., did it occur prior to the offense, during the offense, or when already within the criminal justice system?).

Further, there is a lack of consideration to different severity levels of TBI. It would be expected that a degree of dose-response would be evident, such that those with more severe injury would be likely to demonstrate a greater number of problems. However, a number of the studies reviewed reported that a history of TBI, regardless of age of injury, or injury severity - including concussion, was reported as being associated with negative outcomes. One of the few studies in which the issue of injury severity was evaluated was conducted by Kaba et al. [48], whereby outcomes were compared between 300 males who have been in the criminal justice system for some time, and 84 males new to the system, separating TBI according to injury severity. In doing this, the study reported that those with more severe injury used significantly more in-jail mental health services than those with injury or minimal injury without altered state of consciousness [48].

The importance of appropriate control groups is highlighted by the prevalence of self-reported TBI within nonincarcerated samples who have co-occurring mental health problems as shown on Table 3. The 
presence of drug and alcohol abuse problems is associated with an increased prevalence of self-reported TBI among nonincarcerated samples and at a similar rate to those within the criminal justice system. The general lack of control for preinjury functioning in the existing literature, or in some cases the lack of an appropriate control group, limits the degree to which the relationship between these outcomes and TBI can be evaluated.

\section{Is there a link between TBI \& criminal offending behaviors among criminal justice populations?}

Perhaps more problematic in terms of examining whether a history of TBI increases negative outcomes for criminal justice populations is that very few studies have explored whether the self-reported TBI predated first contact with the legal system. Notable exceptions to this were a study in which the authors examined age at first injury, and reported an association between TBI and earlier initiation of drug use [38]. To examine the association between negative outcomes, offending behaviors and TBI, research protocol will require some attention to the timing of the TBI event. If the TBI event occurs after first contact with the legal or mental health system, the association with TBI is not clear. In many of the studies reviewed, an attempt to overcome this confound is made by using a control group which consists of individuals within the criminal justice system who do not have a self-reported history of TBI. However, this type of control does not overcome the possibility that the increased mental health issues and drug and alcohol misuse, also increase the likelihood of a TBI event occurring.

\section{Outcomes for female offenders}

Female and males within the criminal justice system unsurprisingly have different characteristics [71]. Therefore, it is essential that the outcomes for such female samples with TBI be considered separately from those of males. However, generally where females have been included in samples, results are not examined separately, obscuring the outcomes for female with TBI in the criminal justice system. Exceptions to this include the study of [27], where outcomes for females were exclusively examined (individuals charged for violent vs nonviolent offences), and reported that $95 \%$ of all individuals had neurological abnormalities predating their offence. Further, a history of TBI was also found to be higher among those charged with violent offences [27]. When comparing male and female adolescents newly admitted into the criminal justice system, for those with more severe TBI, females were more likely to use mental health services, whereas males were more likely to commit another offence [48]. This finding is consistent with previous research on general community populations where differences between males and females with TBI have been reported. In one recent study, it was reported that females were more likely to have internalizing disorders (depression, anxiety) and males having higher rates of eternizing disorders (offending behavior, property damage) [72]. These differences between males and females in terms of outcomes following TBI have significant implications in terms of the rehabilitation and support services required for each of the groups within the criminal justice system.

\section{Conclusion}

TBI has been associated with diminished coping skills, judgment and impulse control, difficulties with emotion recognition and poor emotional regulation. Given that these characteristics are also found among individuals who are charged with an offence, it is not surprising that the association between TBI and offending behaviors has become increasingly important to consider, both in terms of initial offending pathways and rehabilitation of such populations, particularly those within the criminal justice system. Research reviewed here suggests high prevalence of TBI among criminal justice populations, with up to $88 \%$ reporting a TBI event in some groups. Further, a history of TBI has been associated with increased rates of violent behavior, increased drug and alcohol use, deficits in cognitive functioning and increased mental health problems. It is evident from the high rates of TBI among criminal justice populations that there is a clear need for consideration regarding how this injury might impact on an individual's behavior while present within the criminal justice system, and how rehabilitation may have to be targeted if recidivism is to be successfully reduced.

However, from the extant research, it is not possible to accurately identify the prevalence of TBI among criminal justice populations, or whether TBI is in fact more frequent among these populations than within the general community, because community samples where self-report has been used and where a similar disadvantage is present, share similar reported prevalence rates. Further, there remains a need to more clearly clarify the direction of the relationship between TBI and offending behavior and its association with mental health outcomes.

\section{Value of accurate identification of individuals with TBI}

As outlined earlier, those within the criminal justice system with a history of TBI may be more likely to 
be aggressive in challenging situations, and their ability to benefit from traditional rehabilitation programs requires evaluation in the context of cognitive or emotional problems that may exacerbate other issues [14,15]. It is, therefore, of value to identify a previous history of $\mathrm{TBI}$ and modify rehabilitation programs to maximize success. It is worth noting that for many individuals who experience TBI, even severe TBI, may not have previously had access to appropriate rehabilitation services following the acute period of recovery [73]. Further, it is not uncommon for children in particular to be expected to make a full and spontaneous recovery due to the notion of unlimited neuroplasticity [74,75]. Therefore, to be effective, any screening and subsequent intervention plan would have to be able to accommodate recent and historic TBI events. This notion of historic event is particularly important because a youth or adult with a history of an unrecognized severe brain injury who did not receive input would have an early trajectory of social and academic disadvantage [5].

While it is beyond the scope of this manuscript to discuss treatment plans, it is worth noting that organizations such as The Centers for Disease Control [76], brainline.org [77] and the North American Brain Injury Society [78] provide extensive information regarding interventions appropriate for individuals with TBI.

\section{Future perspective}

Unfortunately, accurate assessment of TBI prevalence rates among criminal justice groups is hampered by the reliance on self-report to ascertain cases of TBI, the use of inconsistent terminology and varying age ranges of the samples selected.

Further, because prevalence estimates for these populations rely on self-report and use inclusion criteria for defining TBI severity which differs from what is normally accepted for the general population, it is impossible to determine whether TBI is a risk factor for offending behavior and mental health problems. Moreover, little attention has been paid to whether an identified TBI event predates any offending behav- ior, making it difficult to evaluate the direction of the association between TBI and offending.

Moving forward, prevalence rates for individuals within the criminal justice system need to be validated against medical records. Using medical records would enable inclusion criteria that more closely resemble those used in community populations and would allow for direct comparison. It could be argued that not all offenders will seek medical attention for a TBI. However, there is no evidence that criminal justice populations are any less likely to seek medical attention than the general population. The greater problem remains that individuals do not have a good recall past TBI events and, perhaps more problematic, report false positives more frequently than true positives. In cases where only self-report is available, a careful approach to eliciting events is required. This approach should include the following: cueing of recall via multiple questions regarding how TBI events might have taken place; ensure the person has an understanding of different TBI terminology that may have been used to describe a past TBI injury; ensure that symptoms associated with TBI is elicited so that false understanding does not create false negatives, that is, the belief for some that a TBI requires LOC; ensure reported injury events are TBI and not confused with other injury events. No such instrument currently exists.

Further, to identify the direction of association information needs to be collected regarding when the TBI event occurred, and the timing of first offending behavior or contact with mental health services. Moreover, with the increasing numbers of females entered into the criminal justice system, it is essential that outcomes of TBI be considered for females separately to males to more clearly identify the particular needs of each group. Without more detailed examination of criminal justice populations, it will not be possible to illuminate the direction of association between TBI and offending behavior, and rehabilitation input will not be targeted to those who need it the most.

\section{Executive summary}

- There is increasing scrutiny to determine whether traumatic brain injury (TBI) is more prevalent among individuals within the criminal justice system. However, the current literature is fraught with methodological issues which are covered in the following areas:

- Lifetime prevalence of TBI among individuals present within the criminal justice system highlighting methodological issue that explained variations.

- TBI is not more prevalent among criminal justice populations, but comparable with similar subgroups in the general population.

- There is inconsistent evidence as to whether TBI among criminal justice populations is associated with increased negative behavioral, psychological or social outcomes.

- The possible link between increased prevalence of TBI, among criminal justice populations and mental health problems is obscured by insufficient information about the timing of injury. 
Financial \& competing interests disclosure

The authors have no relevant affiliations or financial involvement with any organization or entity with a financial interest in or financial conflict with the subject matter or materials discussed in the manuscript. This includes employment, consultancies, honoraria, stock ownership or options, expert testimony, grants or patents received or pending, or royalties.

\section{References}

1 Buka S, Earls F. Early determinants of delinquency and violence. Health Aff. 12(4), 46-64 (1993).

2 Lewis DO, Pincus JH, Bard B et al. Neuropsychiatric, psychoeducational, and family characteristics of 14 juveniles condemned to death in the United States. Am. J. Psychiatry 145, 584-589 (1998).

3 Lewis DO, Pincus JH, Feldman M, Jackson L, Bard B. Psychiatric, neurological, and psychoeducational characteristics of 15 death row inmates in the United States. Am. J. Psychiatry 143(7), 838-845 (1986).

4 Timonen M, Miettunen J, Hakko H et al. The association of preceding traumatic brain injury with mental disorders, alcoholism and criminality: The Northern Finland 1966 Birth Cohort Study. Psychiatry Res. 113(3), 217-226 (2002).

5 Mckinlay A, Corrigan J, Horwood L, Fergusson D. Substance abuse and criminal activities following traumatic brain injury in childhood, adolescence, and early adulthood. J. Head. Trauma Rehabil. 29(6), 498-506 (2014).

6 Bufkin JL, Luttrell VR. Neuroimaging studies of aggressive and violent behavior: current findings and implications for criminology and criminal justice. Trauma Violence Abuse 6(2), 176-191 (2005).

7 Raine A. Annotation: the role of prefrontal deficits, low autonomic arousal, and early health factors in the development of antisocial and aggressive behavior in children. J. Child Psychol. Psychiatry 43(3), 417-434 (2002).

8 Bechara A, Damasio H, Damasio AR. Emotion, decision making and the orbitofrontal cortex. Cereb. Cortex 10(3), 295-307 (2000).

9 Bechara A, Damasio AR, Damasio H, Anderson SW. Insensitivity to future consequesnces following damage to human prefrontal cortex. Cognition 50, 7-15 (1994).

10 Bechara A. The role of emotion in decision-making: evidence from neurological patients with orbitofrontal damage. Brain Cogn. 55(1), 30-40 (2004).

11 Bechara A, Tranel D, Damasio H, Damasio AR. Failure to respond autonomically to anticipated future outcomes following damage to prefronal cortex. Cereb. Cortex 6, 215-225 (1996).

12 Sufka KJ, Lynch MP. Sensations and pain processes. Philos. Psychol. 13(3), 200-211 (2010).

13 Mclellan T, Mckinlay A. Sensitivity to emotion, empathy and theory of mind: adult performance following childhood TBI. Brain Inj. 27(9), 1032-1037 (2013).

14 Baguley IJ, Cooper J, Felmingham K. Aggressive behavior following traumatic brain injury. How common is common? J. Head Trauma Rehabil. 1(29), 45-56 (2006).
No writing assistance was utilized in the production of this manuscript.

\section{Open access}

This work is licensed under the Creative Commons Attribution 4.0 License. To view a copy of this license, visit http://creativecommons.org/licenses/by/4.0/

15 Rao V, Rosenberg P, Bertrand M et al. Aggression after traumatic brain injury: prevalence and correlates. J. Neuropsychiatry Clin. Neurosci. 21(4), 420-429 (2009).

16 Cunningham MD, Vigen MP. Death row inmate characteristics, adjustment, and confinement: a critical review of the literature. Behav. Sci. Law. 20, 191-210 (2002).

17 Wortzel HS, Arciniegas DB. A forensic neuropsychiatric approach to traumatic brain injury, aggression and suicide. J. Am. Acad. Child Adolesc. Psychiatry 41, 274-286 (2013).

18 Steinberg L. Cognitive and affective development in adolesecence. Trends Cogn. Sci. 9(2), 69-74 (2005).

19 Mental Health Services in Australia. Australian Institute of Health and Welfare (AIHW) 2007. Mental health services in Australia 2004-05. AIHW cat no. HSE 47. Canberra: AIHW (Mental Health Series no. 9). www.aihw.gov.au

20 Gatti U, Tremblay RE, Vitaro F. Iatrogenic effect of juvenile justice. J. Child Psychol. Psychiatry 50(8), 991-998 (2009).

21 Merbitz CT, Jain S, Good GL, Jain A. Reported head injury and disciplinary rule infractions in prison. J. Offender Rehabil. 22, 11-19 (1995).

22 Barnfield TV, Leathem JM. Incidence and outcomes of traumatic brain injury and substance abuse in a New Zealand prison population. Brain Inj. 12, 455-466 (1998a).

23 Barnfield TV, Leathem JM. Neuropsychological outcomes of traumatic brain injury and substance abuse in a New Zealand prison population. Brain Inj. 12(11), 951-962 (1998b).

24 Morrell RF, Merbitz CT, Jain S, Jain S. Traumatic brain injury in prisoners. J. Offender Rehabil. 27(3-4), 1-8 (1998).

25 Leon-Carrion J, Ramos FJC. Blows to the head during development can predispose to violent criminal behavior: rehabilitation to consequences of head injury is a measure for crime prevention. Brain Inj. 17(3), 207-216 (2003).

26 Slaughter B, Fann JR, Ehde D. Traumatic brain injury in a county jail population: prevalence, neuropsychological functioning and psychiatric disorders. Brain Inj. 17(731-741), 731-741 (2003).

27 Brewer KS, Burgess AW, Shults J. Physical and sexual abuse, salivary cortisol, and neurologic correlates of violent criminal behaviour in female prison inmates. Biol. Psychiatry 55, 21-31 (2004)

28 Schofield PW, Butler T, Hollis S, Smith NE, Lee SJ, Kelso WJ. Traumatic brain injury among Australian prisoners: rates, recurrence and sequelae. Brain Inj. 20, 499-506 (2006).

29 Schofield PW, Butler T, Hollis S, Smith NE, Lee SJ, Kelso WM. Traumatic brain injury among Australain prisoners: rates, recurrence and sequelae. Brain Inj. 20(5), 499-506 (2006). 
30 Colantonio A, Stamenova V, Abramowitz C, Clarke $\mathrm{D}$, Christensen B. Brain injury in a forensic psychiatric population. Brain Inj. 21, 1353-1360 (2007).

31 Diamond PM, Harzke AJ, Magaletta PR, Cummins AG, Frankowski R. Screening for traumatic brain injury in an offender sample: a first look at the reliability and validity of the Traumatic Brain Injury Questionnaire. J. Head Trauma Rehabil. 22(9), 330-338 (2007).

32 Bogner JA, Corrigan JD. Reliability and predictive validity of the Ohio State University TBI identification method with prisoners. J. Head Trauma Rehabil. 24(4), 279-291 (2009).

33 Perkes I, Schofield PW, Butler T, Hollis S. Traumatic brain injury rates and sequelae: a comparison of prisoners with a matched community sample in Australia. Brain Inj. 25(2), 131-141 (2011).

34 Ferguson PL, Pickelsimer EE, Corrigan JD, Bogner JA, Wald M. Prevalence of traumatic brain injury among prisoners in South Carolina. J. Head Trauma Rehabil. 27(3), E11-E20 (2012).

35 Colantonio A, Kim H, Allen S, Asbridge M, Petgrave J, Brouchu $S$. Traumatic brain injury and early life experiences among men and women in a prison population. J. Correct. Health Care 20(4), 271-279 (2014).

36 Ray B, Sapp D, Kincaid A. Traumatic brain injury among Indiana state prisoners. J. Forensic Sci. 59(5), 1248-1253 (2014).

37 Durand E, Waiter L, Fix M, Weiss JJ, Chevignard M, Paradat-Diehl P. Prevalence of traumatic brain injury and epilepsy among prisoners in France: results of the Fleury TBI study. Brain Inj. doi:10.3109/02699052.2015.1131848 (2016) (Epub ahead of print).

38 Fishbein D, Dariotis JK, Ferguson PL, Pickelsimer EE. Relationships between traumatic brain injury and illicit drug use and their association with aggression in inmates. Int. J. Offender Ther. Comp. Criminol. 60, 575-597 (2016).

39 Woolhouse R, Mckinlay A, Grace RC. Women in prison with traumatic brain injury: prevalence, mechanism and impact on mental health. http://ir.canterbury.ac.nz

40 Hux K, Bond V, Skinner S, Belau D, Sanger D. Parental report of occurrences and consequences of traumatic brain injury among delinquent and non-delinquent youth. Brain Inj. 12(8), 667-681 (1998).

41 Forrest CB, Tambor E, Riley AW, Ensminger E, Starfield $B$. The health profile of incarcerated male youths. Pediatrics 105, 286-291 (2000).

42 Kenny DT, Lennings CJ. The relationship between head injury and violent ofending in juvenile detainees. Crime Justice (107), 1-15 (2007).

43 Perron BE, Howard MO. Prevalence and correlates of traumatic brain injury among delinquent youths. Crim. Behav. Ment. Health 18 243-255 (2008).

44 Williams WH, Cordan G, Mewse AJ, Tonks J, Burgess CNW. Self-reported traumatic brain injury in male youth offenders: a risk for re-offending, poor mental health and violence? Neuropsychol. Rehabil. 20(6), 801-812 (2010).
45 Williams W, Mewse A, Tonks J, Mills S, Burgess C, Cordan $\mathrm{G}$. Traumatic brain injury in a prison population: prevalence and risk for re-offending. Brain Inj. 24(10), 1184-1188 (2010).

46 Davies RC, Williams WH, Hinder D, Burgess CNW, Mounce LTA. Self-reported traumatic brain injury and postconcussive symptoms in incarcerated youth. J. Head Trauma Rehabil. 27(3), E21-E27 (2012).

47 Moore E, Indig D, Haysom L. Traumatic brain injury, mental health, substance use, and offending among incarcerated young people. J. Head Trauma Rehabil. 29(3), 239-247 (2014).

48 Kaba F, Diamond PM, Haque A, Macdonald R, Venters H. Traumatic brain injury among newly admitted adolescents in the New York city jail system. J. Adolesc. Health 54, 615-617 (2014).

49 Chistabesan P, Lennox C, Williams WH, Tariq O, Shaw J. Traumatic brain injury in juvenile offenders: findings from the comprehensive health assessment tool study and the development of a specialist linkworker service. J. Head Trauma Rehabil. 30(2), 106-115 (2015).

50 Mckinlay A, Bishop A, Mclellan T. Public knowledge of 'concussion' and the different terminology used to communicate about mild traumatic brain injury (MTBI). Brain Inj. 25(7), 761-766 (2011).

51 Corrigan JD, Deutschle JJ. The presence and impact of traumatic brain injury among clients in treatment for co-occuriring mental illness and substance abuse. Brain Inj. 22(3), 223-231 (2009).

52 Anstey KJ, Butterworth P, Jorm AF, Christensen H, Rodgers $\mathrm{B}$, Windsor TD. A population survey found an association between self-reports of traumatic brain injury and increased psychiatric symptoms. J. Clin. Epidemiol. 57(11), 1202-1209 (2004).

53 Fife D. Head injury with and without hospital admission: comparisons of incidence and short-term disability. Am. J. Public Health 77, 810-812 (1987).

54 Sosin DM, Sniezek JE, Thurman DJ. Incidence of mild and moderate brain injury in the United States, 1991. Brain Inj. 10(1), 47-54 (1996).

55 Mckinlay A, Grace R, Horwood L, Fergusson D, Ridder E, Macfarlane M. Prevalence of traumatic brain injury amond children, adolescents and young adults: prospective evidence from a birth cohort. Brain Inj. 22(2), 175-181 (2008).

56 Feigin VL, Theadom A, Barker-Collo $\mathrm{S}$ et al. Incidence of traumatic brain injury in New Zealand: a population-based study. Lancet Neurol. 12, 53-64 (2013).

57 Mckinlay A, Kyona E, Grace RC, Horwood LJ, Fergusson DM, Macfarlane MR. An investigation of the pre-injury risk factors associated with children who experience traumatic brain injury. Injury Prev. 16(1), 31-35 (2010).

58 Dams-O'connor K, Cantor JB, Brown M, Dijkers MP, Spielman LA, Gordon WA. Screening for traumatic brain injury: findings and public health implications. J. Head Trauma Rehabil. 29(6), 479-489 (2014).

59 Cassidy JD, Boyle E, Carroll LJ. Population-based, inception cohort study of the incidence, course, and prognosis of mild 
traumatic brain injury after motor vehicle collisions. Arch. Phys. Med. Rehabil. 95(3), S278-S285 (2014).

Segalowitz SJ, Brown D. Mild head injury as a source of developmental disabilities. J. Learn. Disabil. 24, 551-558 (1991).

61 Cantor JB, Gordon WA, Schwartz ME, Charatz HJ, Ashman TA, Abramowitz S. Child and parent responses to a brain injury screening questionnaire. Arch. Phys. Med. Rehabil. 85(2), S54-S60 (2004).

Body C, Leatham J. Incidence and aetiology of head injury in a New Zealand adolescent sample. Brain Inj. 10, 567-573 (1996).

63 Whiteneck GG, Cuthbert JP, Corrigan JD, Bogner JA. Prevalence of self-reported lifetime history of traumatic brain injury and associated disability: a statewide population-based survey. J. Head Trauma Rehabil. 31(1), E55-E62 (2016).

64 Jaff MP, O'neill J, Vandergoot D, Gordon WA, Small B. The unveiling of traumatic brain injury in an HIV/AIDS population. Brain Inj. 14, 35-44 (2000).

65 Ramesh D, Keyser-Marcus LA, Ma L et al. Prevalence of traumatic brain injury in cocaine-dependent research volunteers. Am. J. Addict. 24, 341-347 (2015). McHugo GJ, Krassenbaum S, Donley S, Corrigan JD, Bogner JA, Drake RE. The prevalence of traumatic brain injury among people with co-occurring mental health and substance use disorders. J. Head Trauma Rehabil. doi:10.1097/HTR.0000000000000249 (2016) (Epub ahead of print).

67 Schofield PW, Butler T, Hollis S, D'este C. Are prisoners reliable survey respondents? A validation of self-reported traumatic brain injury (TBI) against hospital medical records. Brain Inj. 25, 74-82 (2011).

68

Mckinlay A, Horwood LJ. The accuracy of adult recall for early mild traumatic brain injury. Disabil.
Rehabil. doi:10.1080/09638288.2016.1193905 (2016) (Epub ahead of print).

69 Mckinlay A, Horwood LJ, Fergusson DM. Accuracy of self-report as a method of screening for lifetime occurrence of traumatic brain injury events that resulted in hospitalisation. J. Int. Neuropsychol. Soc. 22(77), 717-723 (2016).

70 Mccrae MA. Mild Traumatic Brain Injury and Postconcussion Symdrome. Oxford University Press, Oxford, UK (2008).

71 Bloom B, Owen B, Covington S. National Institute of Corrections. Gender-responsive strategies (2003). http://static.nicic.gov/Library/018017.pdf

72 Scott C, Mckinlay A, Mclellan T, Britt E, Grace RC, Macfarlane MR. A comparison of adult outcomes for males compared with females following pediatric traumatic brain injury. Neuropsychology 29, 501-508 (2015).

73 Mckinlay A, Linden M, Depompei R et al. Service provision for children and young people with acquired brain injury: practice recommendations. Brain Inj. doi:10.1080/02699052 .2016 .1201592 (2016) (Epub ahead of print).

74 Hawley CA, Ward AB, Magnay AR, Long J. Outcomes following childhood head injury: a population study. J. Neurol. Neurosurg. Psychiatry 75, 737-742 (2004).

75 Anderson V, Spensor-Smith M, Wood A. Do children really recover better? Neurobehavioural plasticity after early brain insult. Brain 134(8), 2197-2221 (2011).

76 Centers for Disease Control and Prevention. Injury prevention \& control: traumatic brain injury \& concussion. www.cdc.gov/TraumaticBrainInjury/index.html

77 brainline.org. www.brainline.org

78 North American Brain Injury Society. www.nabis.org/ 